\section{Między pamięcią a historią. Pisarze żydowscy pochodzenia maghrebskiego we Francji. Perspektywa socjologiczna}

Ewa Tartakowsky

TEKSTY DRUGIE 2016, NR 3, S. 356-374

DOI: $10.18318 /$ td. 2016.3 .19

$\mathbf{T}$ wórczość pisarzy żydowskich pochodzenia maghrebskiego powoli wpisała się w pejzaź literatury francuskiej. Jest ona owocem pracy ponad stu autorów uprawiających różne formy wypowiedzi literackiej - fikcję, autobiografię, poezję, dramat-chociaż to powieść i, ogólniej, teksty prozatorskie zajmują w niej miejsce dominujące'. W grupie tej pojawiają się zarówno pisarze uznani, jak Hélène Cixous, Colette Fellous czy Hubert Haddad; autorzy, którzy zdobyli sławę, uprawiając inny zawód, stanowiący dla nich źródło utrzymania, jak Alexandre Arcady, Jacques Attali, Gisèle Halimi, Enrico Macias, Albert Memmi lub Serge Moati; twórcy, którzy nie należą do świata literackiego w ścisłym sensie, ale wydali liczne dzieła, które zdobyły pewien rozgłos medialny, jak

1 Powieść jest gatunkiem najszerzej reprezentowanym $w$ ramach tej twórczości $(67 \%)$. Dominowała ona również w literaturze kolonialnej, stanowiącej literacki punkt odniesienia dla żydowskich pisarzy pochodzących z Maghrebu. Zob. G. Dugas Bibliographie critique de la littérature judéo-maghrébine d'expression française (1896-1990), L'Harmattan, Paris 1992, s. 41 [wszystkie przypisy pochodzą od autorki artykułu].
Przektad z języka francuskiego Przemysława Szczura zmienionei wersji artykułu pt. Entre mémoire ethistoire. Ecrivains

d'origine judéo-maghrébine en France. Une approche sociologique, Tsafon. Revue d'études juives du Nord, nr 70, jesiér 2015 - zima 2016, s. $61-81$.
Ewa Tartakowsky

- dr, asystentka na wydziale socjologii Universytetu Paris 10, członek zespołu badawczego Centre Max Weber (Lyon). Interesuje się literaturą mıgracyjną, historią I kulturą Żydów we Francji, socjologią pamięci i epistemologią historyczną. Ostatnio opublikowała: Les luifs et le Maghreb. Fonctions sociales d'une littérature d'exil, Tours, Presses universitaires François Rabelais, 2016. Kontakt: etartakowsky@ yahoo.fr 
Rolland Doukhan, Pol Serge Kakon, Monique Zerdoun; autorzy pojedynczych utworów, które nie przeszły bez echa, nie stały się jednak zaczątkiem kariery literackiej, jak Katia Rubinstein, Paule Darmon, Annie Goldmann, Jean-Luc Allouche; i wreszcie twórcy publikujący swoje dzieła własnym sumptem, jak Georges Cohen, Viviane Scemama-Lesselbaum czy Edmond Zeitoun.

Aby zbadać ten wymiar ich dzieł, który związany jest z migracją², świadomie wyjdę poza podejście czysto estetyczne i ujmę tę twórczość w perspektywie całościowej. By zaś zrozumieć warunki, w jakich się ona wyłoniła, konieczne będzie wpisanie autorów, o których mowa, w ramy epoki, w jakiej przyszło im żyć, a więc nakreślenie warunków historycznych, z którymi

2 W wersji francuskiej artykułu użyto terminu „exil", który odsyła zarówno do przesiedlenia, jak i do statusu wygnańca (zob. A. Nuselovici (Nouss) Exiliance: condition et conscience, wersja robocza przedstawiona na seminarium "L'expérience de l'exil", zorganizowanym w ramach programu "Non-lieux de l'exil", FMSH-WP-2013-44, we wrześniu 2013 roku). Tłumaczenie terminu "exil" na język polski jako "wygnania" nie byłoby trafne, ponieważ Żydzi nie zostali formalnie wypędzeni z krajów Maghrebu, choć oczywiście praktyki, jakie wobec nich stosowano, wpisywały się w proces tworzenia wykluczających wspólnot narodowych. Użycie terminu "wygnanie", którego najbliższymi francuskimi odpowiednikami są "exode” oraz „expulsion", przenosiłoby poza tym akcent na przebieg procesu wypędzania z kraju pochodzenia, natomiast francuskie "exil" pozwala skoncentrować się na wspólnocie przyjmującej. A to właśnie ta ostatnia jest tutaj głównym przedmiotem analizy. Z tych samych powodów niewłaściwe byłoby tłumaczenie wyrażenia „, ittérature d’exil” jako „literatura wygnańcza” lub „przesiedleńcza”. Po pierwsze, Żydzi maghrebscy nie doznali prześladowań podobnych do tych, jakich doświadczyli Żydzi w innych krajach muzułmańskich, takich jak Liban, Irak czy Egipt. Po drugie, użycie tych terminów wiązałoby się z wpisaniem analizowanych dzieł w nurt historiograficzny nazywany "tzawym" (néo-lacrymal; zob. M.R. Cohen Islam and the Jews: Myth, Counter-Myth, and History, "Jerusalem Quartely" 1986, no. 38, s. 125-137). Nurt ten skupia się na upokorzeniach, wynikających z zimmy (arab. „pakt”) narzuconej Żydom, której ostatnim aktem miałoby być masowe opuszczanie przez nich krajów muzułmańskich. Tymczasem pisarze żydowscy pochodzenia maghrebskiego w większości nie przyjmują takiej perspektywy, kładąc w swoich utworach nacisk raczej na pokojowe współżycie z muzułmanami. Polskie terminy "literatura emigracyjna" czy "literatura wychodźcza", czasami stosowane jako tłumaczenia francuskiego wyrażenia "littérature d'exil”, są trafne w odniesieniu do niektórych korpusów. Byłyby jednak mylące w przypadku analizowanej tutaj twórczości. W istocie wszyscy Żydzi algierscy posiadali obywatelstwo francuskie, a więc nie emigrowali w ścisłym tego słowa znaczeniu, gdyż kolonialna Algieria posiadała status francuskiego departamentu. Wyjechali oni zresztą w większości między kwietniem a czerwcem 1962 roku, a więc po podpisaniu porozumień z Évian w marcu 1962 roku, a przed ogłoszeniem niepodległości przez Algierię 5 lipca 1962 roku. Oczywiście działo się to tuż przed ogłoszeniem niepodległości, jednak formalnie nie chodziło o emigrację z jednego kraju do drugiego. Sytuacja jest bardziej złożona w przypadku Maroka i Tunezji, gdyż wyjazdy były bardziej rozłożone w czasie; trudno by jednak było przyjąć termin emigracja czy imigracja, gdyż korpus obejmuje dzieła żydowskich pisarzy pochodzących z całego Maghrebu. Dlatego w polskiej wersji artykułu przyjęto termin " literatura migracyjna". 
musieli się zmagać. Czynnikiem decydującym była tu masowa migracja Żydów maghrebskich ${ }^{3}$ w związku z odzyskaniem niepodległości przez kraje Maghrebu.

Nie oznacza to jednak, że autorzy ci nie zostaliby pisarzami, gdyby nie doświadczenie migracji. Jednak obciążenie psychologiczne, historyczne i społeczne zwiąane z koniecznością opuszczenia rodzinnej ziemi przez dziesiątki tysięcy osób musiało znaleźć artystyczny lub literacki wyraz w ich twórczości.

Uderzająca jest zwłaszcza powszechność pewnych tematów. Wszyscy pisarze żydowscy pochodzenia maghrebskiego, którzy doświadczyli tego geograficznego i społecznego zerwania w okresie dekolonizacji, a mieszkają lub mieszkali we Francji metropolitalnej, podejmowali, w sposób systematyczny lub przygodny i na różne sposoby, tematykę związaną z migracją, wykorzenieniem, zerwaniem czy zetknięciem się z odmiennością, które pozostaje nieodłącznie związane z kondycją migranta w sensie geograficznym i kulturowym. Nie twierdzę, że zachodzi tu jakiś decydujący czy automatyczny determinizm - wszakże nie wszyscy Żydzi pochodzący z Afryki Północnej zostali pisarzami - jednak migracja, jako kluczowe doświadczenie, wpłynęła na wybór tematów przez tych, którzy poświęcili się twórczości literackiej. Jako wydarzenie węzłowe w biografii tych autorów, stanowiła ona jednocześnie traumę zbiorową.

O ile typ idealny twórcy żydowskiego pochodzącego z Maghrebu ${ }^{4}$ nie wykazuje, z perspektywy socjologicznej, różnic w porównaniu z pozostałymi uczestnikami pola literackiego, związki kariery literackiej tych pisarzy w ramach właściwego im podpola (sous-champ) z różnymi aspektami migracji pozwalają ocenić wagę tego szczególnego doświadczenia.

3 Dane szacunkowe mówią o ok. 60000 Żydów tunezyjskich, którzy przeprowadzają się do Francji metropolitalnej, podobna grupa wyjeżdża do Izraela; ponad 210000 Żydów marokańskich emigruje do Izraela w latach 1948-1975 (35 000 wyjechało do Francji, pozostali do Kanady i, w mniejszym stopniu, do Hiszpanii); większość Żydów algierskich, którzy posiadali obywatelstwo francuskie, wybrała Francję (czyli $110000-120000$ ze 140 000). Zob. D. Bensimon, S. Della Pergola Structures démographiques de la population juive originaire d'Afrique du Nord, w: Les Juifs du Maghreb, diasporas contemporaines, réd. J.-C. Lasry, C. Tapia, Presses de l'Université de Montréal, Montréal 1989, s. 179-206.

4 Charakteryzuje się on liczebną przewagą mężczyzn (64\%), nadreprezentacją osób dobrze wykształconych (74\% posiada wyższe wykształcenie), a także podobnym rozkładem „drugich zawodów" ( $28 \%$ stanowią nauczyciele na różnych poziomach kształcenia, $12 \%$ dziennikarze ${ }_{t} 10 \%$ artyści sceniczni oraz pracownicy sektora audiowizualnego, 15\% wolne zawody, $10 \%$ reprezentanci innych zawodów lub bez zawodu). 
Pierwszą przesłanką fundamentalnej roli, jaką odegrała migracja we wkroczeniu przez nich na pole literackie, jest to, że $77 \%$ autorów analizowanych dzieł poświęciło jej swój debiutancki utwór, w sposób mniej lub bardziej otwarty przekształcając literacko swoje doświadczenia społeczne. Migracja determinuje więc bardzo wyraźnie społeczną topikę narracji literackich. I tak 68\% utworów należących do korpusu, na którym opiera się niniejsze studium $^{5}$, odwołuje się do toposu migracji, a $73 \%$ autorów odnosi się do niego przynajmniej raz w tytułach swoich dzieł. Liczby te, chociaż nie obejmują wszystkich, potwierdzają decydujący wpływ migracji na wkroczenie przez tych twórców na pole literackie. Należy dodać, że niemal wszyscy znaleźli się w jego obrębie dopiero po przybyciu do Francji metropolitalnej.

Dlatego, o ile pod względem społecznym pisarze żydowscy pochodzenia maghrebskiego charakteryzują się, ogólnie rzecz biorąc, tymi samymi cechami, co twórcy pochodzący z Francji metropolitalnej, migracja pozostaje wich przypadku elementem wspólnym i decydującym o ich odrębności, choć jej konsekwencje były oczywiście różne dla poszczególnych osób.

Jednak również inne zdarzenia przyczyniły się do stworzenia atmosfery sprzyjającej narodzinom szczególnej twórczości literackiej, przy czym należy je rozumieć po prostu jako sprzyjające lub ułatwiające okoliczności. Jeśli chodzi o uwarunkowania społeczno-polityczne, należałoby wspomnieć o kontekście politycznym, w którym, po wojnie sześciodniowej 1967 roku, krystalizuje się "świadomość żydowska", a także o jednoczesnym rozprzestrzenianiu się w sferze publicznej pamięci o Zagładzie, która stanie się nowym paradygmatem wszystkich „bolesnych pamięci" , zasilając w pewien sposób wyobraźnię literacką pisarzy żydowskich z Afryki Północnej. Jednocześnie zdominowanie przez nią dziejów Żydów francuskich wymazuje w pewnym sensie migrację boleśnie przeżywaną przez Żydów maghrebskich, spychając ich historię na margines. To w tym kontekście oraz aby zrównoważyć brak zainteresowania badaniami nad cywilizacją Żydów sefardyjskich,

5 Korpus obejmuje 441 utworów 109 autorów, napisanych i wydanych we Francji od początku lat 50. XX wieku aż po rok 2010, bez względu na sposób publikacji (na koszt wydawcy lub własnym sumptem).

6 A. Wieviorka Vers une communauté? Les/uifs en France depuis la guerre des Six-Jours, w: Les/uifs de France de la Révolution française à nos jours, réd. I.-J. Becker, A. Wieviorka, Liana Levi, Paris 1998, s. 363-371.

7 A. Wieviorka Shoah:les étapes de la mémoire en France, w: Les Guerres de mémoires. La France et son histoire, réd. P. Blanchard, I. Veyrat-Masson, La Découverte, Paris 2008, 5. 116. 
literatura przejmuje odpowiedzialność za pamięć o migracji Żydów z Afryki Północnej.

Równieź zmiana paradygmatu w przedstawianiu i interpretowaniu narodu i jego obrzeży ułatwia nadanie literackiego kształtu pamięciom „wypartym". Pamięć jako przedmiot badań, a także obiekt polityczny, społeczny i medialny wzbudza ożywione dyskusje, począwszy od lat 8o. XX wieku, stając się centralnym elementem tożsamości grup walczących o uznanie. „Epoka pamięci"s napędza i wzmaga namysł epistemologiczny nad opisywaniem przeszłości ${ }^{9}$, co przejawia się w rozpoczęciu dyskusji o fikcyjnej naturze pisarstwa historycznego, ale także o naukowych walorach literatury. Ten trend przybiera w przypadku niektórych Żydów formę poszukiwania przynależności kulturowej, które znajduje wyraz w dziedzinie literatury oraz badań naukowych.

Z kolei wzrost popularności literatur postkolonialnych tłumaczy zainteresowanie wydawców tego rodzaju utworami, prowadzące do rozwoju we Francji twórczości autorów żydowskich pochodzenia maghrebskiego, których również można sytuować w ramach tego nurtu.

\section{Przedstawianie i przeobrażanie rzeczywistości społecznej}

Przedstawiwszy charakterystyke społeczną, należy zastanowić się, co dzieło literackie mówi nam o rzeczj)wistości społecznej. Trzeba więc sprawdzić, w jakim stopniu utwór czerpie z rzeczywistości oraz dokonuje obiektywizacji świata społecznego, ponieważ „modele świata realnego"10 istotnie pozwalają zgłębiać strukturę społeczną, jak równieź jej przekształcenia.

\section{a. Folklor i życie codzienne}

Stwierdzimy wówczas, że świat społeczny wyłaniający się z dzieł pisarzy żydowskich pochodzenia maghrebskiego obejmuje głównie codzienne życie rodzinne. Niczym etnolodzy przywiązują oni wielką wagę do opisów codzienności swojej wspólnoty oraz do szczegółów związanych z północnoafrykańskim folklorem żydowskim.

8 Les Lieux de mémoire, réd. P. Nora, Gallimard, Paris 1984-1987, t. 1-4.

9 J. Lyon-Caen, D. Ribard L'Historien et la Littérature, La Découverte, Par is 2010.

10 Termin zapożyczony od Nelsona Goodmana przez Pierre'a Bourdieu w Regułach sztuki. Genezje istrukturze pola literackiego, przeł. A. Zawadzki, Universitas, Kraków 2001, S. 504. 
Folklor ten, a także opis przesądów żywionych przez Żydów maghrebskich w istocie zajmują miejsce pierwszoplanowe, a odnoszą się zarówno do kultury materialnej (ubiory, talizmany, przedmioty kultu), jak i duchowej (zwyczaje, rozrywki, muzyka, w tym należąca do tradycji arabsko-andaluzyjskiej, czy rytuały odprawiane przy ważnych okazjach). Są one opisywane tak szczegółowo, gdyż we Francji nie zawsze można było je kultywować, zwłaszcza w wymiarze materialnym ${ }^{11}$.

Chęć utrwalenia folkloru ludowego jest widoczna już w utworze La Statue de sel Alberta Memmi, uważanym za pierwowzór tej literatury przez znaczną część omawianych twórców ${ }^{12}$. Narrator opowiada w nim z pewnym strachem o tańcu rytualnym wykonywanym przez swoją matkę, Żydówkę berberyjską. W Les Belles de Tunis Nine Moati wspomina również o przesądach stanowiących część folkloru żydowskiego, a w szczególności o jednym z amuletów mających chronić przed „złym okiem”. Haï, jeden z bohaterów powieści, wyładowuje swoją frustrację, niszcząc talizmany, używane, aby zapewnić narodziny syna ${ }^{13}$. Amulety chroniące przed złym okiem często pojawiają się w innych utworach. W swojej opowieści o charakterze autobiograficznym, Le Chant des êtres, Gil Ben Aych opisuje „komunię" Simona, swojego alter ego. Czytelnik jest w tej scenie stopniowo wprowadzany w kulturę algierskich Żydów, której elementy zostają przedstawione w sposób dydaktyczny:

Cheddaï, złoty klejnot w kształcie hebrajskiego napisu oznaczającego „ochronę życzliwością", pełni w Algierii rolę porównywalną z tą, jaką, jeśli chodzi o noszone znaki, ryba pełni w Tunezji, krzyż w Europie, a niektóre rodzaje piór u Indian. ${ }^{14}$

Dopiero w 2012 roku paryskie Muzeum Sztuki i Historii Ju daizmu zorganizowało pierwszą wystawępoświęconą historii i kulturze Żydów algierskich, zatytułowaną ", Juifs d'Algérie". Stanowiła ona zdaniem organizatorów odpowiedź na dwa fakty: „znaczący wpływ, jaki przenosiny Żydów algierskich do Francji metropolitalnejw 1962 roku wywarły na francuski judaizm oraz zamazanie się pamięci o specyfice judaizmu północnoafrykańskiego, a zwłaszcza algierskiego". Przygotowanie wystawy było możliwe nie tylko dzięki eksponatom z kolekcji państwowych, ale i wystosowanemu rok wcześniej apelowi, w wyniku którego zgromadzono przedmioty i archiwalia prywatne przekazane przez setki rodzin. Zob. prezentację wystawy na stronach Muzeum Sztuki i Histori Judaizmu, http://www.mahj.org/fr/3_expositions/expo-Juifs-d-Algerie.php (26.03.2013).

A. Memmi La Statue de sel, Corréa, Paris 1953. 
Poza funkcją wspomnieniową, w przypadku której odbiorcami są migranci, jest tutaj widoczna obiektywna funkcja adaptacyjna: opowieść ma objaśniać kulturę migrantów wspólnocie przyjmującej. Jednocześnie opisy tych przedmiotów pozwalają grupie migrantów przywołać doświadczenia z przeszłości oraz rozbudzają wspomnienia.

Chęć przekazania opisów dawnego folkloru stanowi więc element pamięciowego odtwarzania, podobnie jak opisy lokalnego życia. Występują one u licznych autorów, którzy wybierają różne miejsca, od przestrzeni otwartych po zamknięte wnętrza domowe. Pisarze stawiają sobie za cel odtwarzanie utraconej atmosfery, przywołując hałasy i odgłosy, zapachy i emocje. Te opisy społeczno-topograficzne wynikają z chęci stworzenia „miejsca antropologicznego", które Marc Augé definuje jako „konkretną i symboliczną konstrukcję przestrzeni [...], do której odnoszą się wszyscy ci, którym przypisuje ona jakieś miejsce"15. Colette Fellous, która może służyć jako typowy przykład tego rodzaju poszukiwań geograficznych, tworzy znaczną część swoich opowieści, jakby była kartografem. W Avenue de France pracy pamięci nadaje rytm przemieszczanie się w przestrzeni:

La porte de France wyznacza więc nadal granicę między miastem europejskim a miastem arabskim. Po jednej stronie teatr, kościół, kasyno, dorożkarze, parasole, hotele i kina. Po drugiej uliczki [...], meczety, przyprawy, biblioteka w suku el-Attarine, osły, studnie, mężczyźni grający w domino w rozśpiewanych kafejkach, bose stopy dzieci i twarze kobiet ukryte pod białymi sari. ${ }^{16}$

Ale przedstawienia hary, żydowskiej dzielnicy Tunisu, bywają często utrzymane w tej samej stylistyce, co opowieści podróźników po Oriencie z początków epoki kolonialnej, jak m.in. u Nine Moati" ${ }^{17}$. Jedna z bohaterek utworu Les Belles de Tunis przychodzi na świat w trudnych warunkach, w ubogim domu w tej dzielnicy:

15 M. Augé Nie-miejsca. Wprowadzenie do antropologii hipernowoczesności, przeł. R. Chymkowski, PWN, Warszawa 2011, s. 34 .

17 L. Heller-Goldenberg La Hara de Tunis dans I'imaginaire de Nine Moati "Cahier d'études maghrébines" 1992, no 4, s. 62-65. 
Pierwsze piętro domów wystawało nad ulicę, pozbawiając ją słońca, światła, życia. Brudnoszare ścieki, które wylewano bezpośrednio na nią, nie mogły wyparować. Drażniący był zwłaszcza zapach, swąd śmieci i martwych zwierząt, pomieszany z odorem zużytego oleju i węgla drzewnego. ${ }^{18}$

Znaczący fakt: Nine Moati, która spędziła dzieciństwo w Tunezji, nigdy nie mieszkała w dzielnicy żydowskiej, którą opisuje w najdrobniejszych szczegółach. Opisy tego samego rodzaju znajdziemy u Annie Goldmann, która również nigdy nie była mieszkanką tunezyjskiej hary ${ }^{19}$.

Pozostajemy tutaj raczej w sferze tworzenia niż pamięciowego odtwarzania, tym bardziej że wszystkie te opisy utrzymane są w tym samym tonie, co orientalistyczne relacje podróżnicze z początków epoki kolonialnej. Jak podkreśla Colette Zytnicki, „hara czy mellah odsyłają do archaicznych społeczeństw, w których wspólnotom religijnym przypisane jest określone miejsce w przestrzeni, w odróżnieniu od miast europejskich, w których jedynym wyróżnikiem staje się powoli pozycja społeczna"20. Współcześni pisarze żydowscy pochodzenia maghrebskiego odwołują się więc do lejtmotywów stanowiących dziedzictwo epoki kolonialnej.

W tych (re)konstrukcjach czas odmierzają liczne odniesienia do życia rodzinnego, często powiązane $\mathrm{z}$ kalendarzem religijnym lub etapami życia postaci (wyjście z domu na dziedziniec kamienicy, później do szkoły, bar micwa itp.), które są następującymi po sobie stadiami socjalizacji. Dzieje się tak dlatego, że, jak wykazuje Joëlle Bahloul, dom stanowi często punkt zaczepienia dla wspomnień i pamięci²1.

Jeśli chodzi o święta religijne, szabat zajmuje miejsce uprzywilejowane, stając się okazją, np. w Rica la vida Pola Serge'a Kakona, do przypomnienia prawdziwych przepisów kulinarnych ${ }^{22}$. Przywoływanie zwyczajów żywieniowych stanowi jedną z powtarzających się strategii w analizowanych utworach. Pisarze chcą w ten sposób ocalić bardzo różne tradycje, właściwe

18 N. Moati Les Belles de Tunis, s. 27.

19 A. Goldmann Les Filles de Mardochée. Histoire d'une émancipation, Denoël-Gonthier, Paris 1979, S. 17 .

C. Zytnicki Les/uifs du Maghreb. Naissance d'une historiographie coloniale, PUPS, Paris $2011_{t}$ s. 33. Métailié, Paris 1992. 
poszczególnym regionom. Ale to wspominanie i odtwarzanie odwołuje się przede wszystkim do pamięci afektywnej, znajdując punkt oparcia w jednostkowych doświadczeniach socjalizacyjnych i odsyłając czytelnika do zmysłów smaku i zapachu.

Opowieści te - jako nośniki „wyidealizowanej pamięci o przeszłości rodzinnej, która musi zostać podtrzymana"23 - konserwują więc kulturę kulinarną zyskującą charakter rytuału przekazywania (rituel de transmission) w sytuacji, gdy rytuały religijne powoli tracą tę funkcję ${ }^{24}$.

W tych opisach utraconej żydowskości z lat minionych pisarze żydowscy pochodzenia maghrebskiego dążą więc przede wszystkim do mnożenia archetypalnych scen z przeszłości, związanych z folklorem, kuchnią, zapachami i lokalnym życiem, domagającymi się ocalenia jako elementy zanikającej pamięci. Pamięć ta jest podtrzymywana przez upiększanie nieistniejącej już rzeczywistości, a jej nośnikiem są często opisy nasycone uczuciami lub odwołujące się do pewnych kodów orientalizmu. Poza wymiarem retrospektywnym, który w rzeczywistości ustanawia zerwanie oraz nieciągłość czasu - przed i po migracji - odwoływanie się do wspomnień dotyczących folkloru Żydów maghrebskich służy zwłaszcza utrzymaniu spójności tożsamościowej przez wypracowywanie wspólnego zasobu odniesień kulturowych.

\section{b. Waga tematyki historycznej}

Dla omawianej twórczości literackiej charakterystyczna jest również wszechobecność tematyki historycznej, oglądanej z perspektywy zbiorowości, która przedefiniowuje się pod wpływem migracji w epoce naznaczonej napięciami związanymi z procesem dekolonizacji i z trudnościami z zadomowieniem się we Francji metropolitalnej. Te dwa ostatnie zjawiska, którym towarzyszy nagła zmiana perspektywy, są źródłem ambiwalentnego stosunku do Francji.

Analiza tego „nowego spojrzenia” wymaga odwołania się do mitów, z których ono wyrosło i które je ukształtowały. Spośród przedstawień $\mathrm{Ma}$ ghrebu sprzed kolonizacji najczęściej wykorzystywaną opowieścią jest mit

23 V. Assan, S. Nizard Les livres de cuisine juive: à la recherche d'un monde perdu? "Archives Juives" 2014, no $47 / 1$, s. 128.

24 S. Mathieu La mémoire restaurée: la cuisine dans les couples mixtes juifs et non juifs, $w$ Ácroire et à manger: religions et alimentation, réd. A. Kanafani-Zahar, S. Mathieu, S. Nizard, AFSR-L'Harmattan, Paris 2007 , s. 168. 
o Kahinie ${ }^{25}$, pozwalający metaforycznie wzmocnić relację tożsamościową z „maghrebskością” właściwą Żydom z Afryki Północnej ${ }^{26}$. Jednak ten powrót do mitycznej postaci z wyidealizowanej przeszłości wyrasta w znacznym stopniu na gruzach innego mitu: harmonijnego współistnienia społeczności żydowskiej i muzułmańskiej.

W związku z tym we wspomnieniach tych pojawiają się często serdeczne przyjaźnie między przedstawicielami obu wspólnot. Ta forma dialogu międzykulturowego pojawia się m.in. w Rica la Vida Pola Serge'a Kakona, gdy opowiada on o swarach i wspólnych wypadach dwóch zgraj chłopców z portu, muzułmańskiej i żydowskiej. Choć opisy te nie są równieź pozbawione wymiaru fantazmatycznego, stanowią wyraz pewnej rzeczywistości społeczno-historycznej, w której sąsiedztwo miało prawdziwą wartość. Inni twórcy dokonują utożsamienia Żydów z Arabami; przeprowadza je Gil Ben Aych za pośrednictwem postaci Mémé, która pochodzi z Algierii i przemierza Paryż ze swoim wnukiem Simonem. Twierdzi ona, że woli Arabów od Francuzów, bo ,[...] tak jak my są arabami [sic!]..."27.

Ale poza tymi rajskimi wizjami współistnienia wspólnot żydowskiej i muzułmańskiej niektórzy autorzy kładą nacisk na brak rzeczywistej wymiany między nimi. Tak np. Marcel Bénabou wspomina,że w Meknesie, jego rodzinnym mieście, ukształtowanym przez rzeczywistość kolonizacji, „pochodzenie etniczne i przynaleźność religijna, które większość ludzi ze sobą myliła [...] odgrywały decydującą rolę"28.

Odtwarzanie, często wyidealizowanego, choć czasem również rzeczywistego pokojowego współistnienia, stanowi wyraz poszukiwania korzeni, które w kontekście geograficznego oraz kulturowego wykorzenienia ma na celu potwierdzenie tożsamości Żydów pochodzących z Afryki Północnej. Choć nie obowiązuje tu dualizm, dokonuje się ono przez przyznanie się do przynależności do wspólnoty arabskiej lub berberyjskiej albo teź zachodniej, francuskiej.

25

Kahina, berberyjska władczyni z plemienia Jarawa, zdobyła sławę jako ta, która na pewien czas zatrzymała ofensywę zbrojną muzułmańskiego zarządcy Egiptu, Hasana ibn an-Nu'umana al-Ghasaniego. WXIV wieku kronikarz Ibn Chaldun przypisuje jej pochodzenie żydowskie, jednak teza ta jest dzisiaj podawana w wątpliwość przez naukowców. sitaires François Rabelais, Tours 2016, s. 150-153.

G. Ben Aych Le Voyage de Mémé, Bordas, Paris 1982, s. 45.

M. Bénabou La Bonne Langue, w: Le Pays natal, réd. L. Sebbar, Elyzad, Tunis 2013, S. 32. 
Sama Francja stanowi miejsce pamięci skupiające ideał emancypacji ${ }^{29}$. Jest to przede wszystkim Francja rewolucyjna, ogłaszająca „wolność, równość i braterstwo" i przyznająca w 1870 roku zbiorowo obywatelstwo francuskie Żydom algierskim. Jej wcieleniem stają się liczne odniesienia polityczne i kulturowe.

Czerpiąc z podświadomości zbiorowej, pisarze żydowscy pochodzenia maghrebskiego rozpowszechniają ten obraz Francji. Na przykład Annie Goldmann opowiada w Les Filles de Mardochée o bezwarunkowej miłości swojego pradziadka do Francji. Mardochée jest w istocie zasymilowanym Żydem, naleźącym do mieszczańskiej elity intelektualnej Tunisu, załoźycielem i redaktorem dziennika, którego tytuł wyraża sam w sobie jego program: „La Justice”. Francja kojarzy mu się z postępem i humanizmem: „to rewolucja uświęciła idee wolności i równości, zniosła niewolnictwo i nadała Żydom status obywateli" ${ }^{30}$. Wielu autorów podejmuje ten temat, często przez pryzmat historii rodzinnej. I tak Serge Moati, urodzony w Tunezji, wspomina swojego dziadka, który „marzy o lepszym społeczeństwie w opiekuńczym cieniu trójkolorowej flagi"31.

Jednak te obrazy „kraju cywilizacji i kultury” przybierają również trywialne lub ironiczne formy, jak u Colette Fellous, która stwierdza z pewną czułością: „Kochaliśmy, nie znając ich, Folies-Bergères, Chat Noir, Moulin Rouge i Châtelet, braliśmy wszystko, jak leci: Bruanta, Dalidę, Treneta, Adamo, Aznavoura i Johnny'ego" 32 .

Co więcej, ta Francja, którą namiętnie kochają, okazuje się, niczym Janus, ojczyzną o dwóch twarzach. Pisarze odkrywają, że proces francuskiej akulturacji oddalił ich zarówno od tożsamości żydowsko-arabskiej, jak i od przeszłości Żydów mieszkających po tej stronie Morza Śródziemnego. Uświadomienie sobie tego prowadzi niektórych do relatywizacji „wkładu cywilizacyjnego" Francji. W świetle nowych identyfikacji ich ubiór, który nie jest „ani całkiem francuski ani całkiem inny"33, symbolizuje, jak u Pola Serge'a Kakona,

29 E. Tartakowsky From one shore, the other.. The image of France in the works of contemporary Judeo-Maghrebi novelists, "Contemporary French and Francophone Studies: Sites", 2013, t. 17, nr 2, s. 154-163.

30 A. Goldmann Les Filles de Mardochée..., S. 59.

31 S. Moati Villa Jasmin, Fayard, Paris 2003, s. 74 .

32 C. Fellous, Le Petit Casino, Gallimard, Paris 1999, s. 33.

33 P.S. Kakon Rica la Vida, s. 196. 
asymilację. Edmond El Maleh określa spodnie mianem „ubrania zdobywców"34, a Monique Zerdoun kładzie nacisk na dystans, jaki ta asymilacja na poziomie stroju wprowadza w relacje między Żydami i muzułmanami ${ }^{35}$.

W tej perspektywie krytycznej nawet wykształcenie zdobyte w szkołach francuskich jawi się w innym świetle, ponieważ patronują mu wielkie postaci z dziejów Francji, Maghreb zaś jest „o dziwo" nieobecny, zarówno na lekcjach historii, jak i geografii, co wywołuje rozdźwięk z otaczającą rzeczywistością. Oto jak Marcel Bénabou ilustruje w swoich wspomnieniach z dzieciństwa spędzonego w Maroku rozziew wynikający z tego francuskiego wykształcenia:

Wartości wpojone mi przez szkołę, przez lektury, prześladowały mnie, sterowały większością moich reakcji. Wszystko, co miałem przed oczyma, niepostrzeżenie traciło na wartości; stąd ciągłe poczucie nostalgii, pomieszanej z frustracją. ${ }^{36}$

Literatura ta stanowi równieź świadectwo traum, jakie u Żydów maghrebskich wywołała Francja: traumy związanej z antysemityzmem rządu Vichy oraz z odzyskaniem niepodległości przez kraje Maghrebu. Dla Żydów algierskich II wojna światowa stanowi wyraźne zerwanie. Dekret Crémieux z roku 1870 zostaje odwołany 7 października 1940 roku, czyli po siedemdziesięciu latach, zrównując ich status z tym przysługującym muzułmanom. Żydzi zostają pozbawieni dostępu do edukacji publicznej i natychmiast wydaleni z francuskich szkół. Pozbawienie obywatelstwa francuskiego przez Pétaina i reżim Vichy postrzegają jako zdradę ideałów rewolucyjnych oraz republikańskich. Monique Zerdoun odtwarza ten szok, opowiadając o odwołaniu dekretu Crémieux: „z wielkim niedowierzaniem, z mieszanką ironii i zdumienia w spojrzeniu, Arabowie patrzyli, jak Żydzi tracą status Francuzów i znów stają się krajowcami (indigènes)"37. Trauma jest tak potężna, że jej echa odnajdujemy nie tylko u twórców pochodzących z Algierii, ale również z Tunezji i Maroka, których przecież odwołanie dekretu zbiorowo nie dotyczyło.

Dekolonizacja stanowi kolejny punkt zwrotny w historii Żydów z Afryki Północnej. Proces, który doprowadził kraje Maghrebu do odzyskania

\footnotetext{
34 E.A. El Maleh Parcours immobile, André Dimanche, Marseille 2000, s. 11.

M. Zerdoun Rue de la mémoire fêlée, Albin Michel, Paris 1990, s. 113.

M. Bénabou Jacob, Ménahem et Mimoun. Une épopée familiale, Seuil, Paris 1995, S. 22. 
niepodległości, wywołał masową migrację. WL'Essuie-mains des pieds Gil Ben Aych wspomina zdarzenie z dzieciństwa, kiedy „wojskowi okupowali Algier, pod koniec wojny w Algierii, a de Gaulle przejął ster rządów"38. Rolland Doukhan w Berechit powraca do zakończenia wojny i porozumień z Évian, aby wyjaśnić migrację tysięcy pieds-noirs ${ }^{39}$ i algierskich Żydów do Francji metropolitalnej: „Pamiętacie Évian? Pokój, tak, pokój, na który nikt już nie liczył, ale wraz z nim wewnętrzne rozdarcie u tysięcy zwykłych ludzi"

Droga do niepodległości pełni podwójną funkcję w tych narracjach: dzięki odniesieniom historycznym nadaje życiu postaci wymiar czasowy, a także przygotowuje czytelników na opowieść o migracji, która staje się punktem węzłowym, centralną traumą.

Kiedy rozpoczyna się proces dekolonizacji, mimo głębokiego poczucia zranienia, wynikającego z postawy rządu francuskiego w trakcie II wojny światowej, spora cześć maghrebskich Żydów wybiera Francję. Decyzję często podejmują w pośpiechu, „w ostatniej chwili”, gdyż nowe państwa wydają się nie pozostawiać miejsca dla mniejszości religijnych. Migracja północnoafrykańskich Żydów pozostanie więc w ich zbiorowej pamięci jako wydarzenie decydujące o ich przynależności, opartej na wspólnym doświadczeniu cierpienia. Marco Koskas opisuje w L'Homme de paille warunki życia w przeludnionych mieszkaniach, w których „mieszkało się w dziewięcioro w dwóch pokojach" "41. Gil Ben Aych również ukazuje ten trudny okres, kiedy cała rodzina musi dostosować się do nowej rzeczywistości, zarówno pod względem materialnym, jak i psychologicznym, wspominając m.in.

38 G. Ben Aych L'Essuie-mains des pieds, Presses d'aujourd'hui, Paris 1981, s. 121.

39 Określenie pieds-noirs odnosi się do Francuzów mieszkających w Algierii francuskiej, a także do tych, którzy zamieszkiwali Tunezję i Maroko jako protektoraty francuskie, aż do odzyskania przez te kraje niepodległości. Chodzi o Francuzów urodzonych we Francji i mieszkających w Algierii oraz w protektoratach, a także o ich potomków. W społeczeństwie kolonialnym, które z góry definiowało oraz odgradzało od siebie grupy społeczne, algierscy Żydzi, mimo że posiadali obywatelstwo francuskie, byli uważani za odrębną społeczność, o czym świadczą ankiety

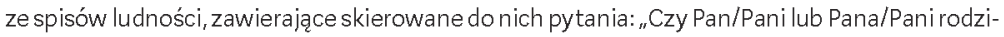
ce jesteście Izraelitami i otrzymaliście obywatelstwo w oparciu o dekret z 1870 roku?". Są więc odróżniani na podstawie kategorii rasowych. Wchwili, gdy opuszczają Algierię, uznaje się ich za część grupy pieds-noirs, korzystającej z pomocy państwa na podstawie ustawy ramowej przyjętej w grudniu 1961 roku, definiującej status repatrianta; w 1962 roku powstaje ministerstwo ds. repatriantów. 
niepokój swojej babki, Étoile, bohaterki jego licznych powieści, którą to „przerastało" 42 .

Przeprowadzka do Francji metropolitalnej będzie naznaczona wieloma trudnymi doświadczeniami na poziomie relacji toźsamościowych, wynikającymi ze zderzenia z utajoną ksenofobią. Stąd nasilenie się krytyki zachodniego etnocentryzmu kulturowego i społecznego. Katia Rubinstein, pochodząca z Tunezji, skarży się na powszechną obojętność:

Czyż nie powtarzano nam, że Paryżanie są ludźmi najbardziej szczodrymi, otwartymi i kulturalnymi? Dlaczego rzeczywistość jest tak inna? [...] Lubi się egzotykę i rozbawienie, w jakie ona wprawia, te wszystkie „Ah! Pan jest Persem!...", ale brak prawdziwego zainteresowania tym, co dzieje się gdzie indziej; ci stamtąd są pasjonujący tylko z daleka, jako sposobność do marzeń, ale kiedy zjawiają się tutaj, odwracamy się do nich plecami. ${ }^{43}$

Poza krytyką wyniosłości charakterystycznej dla cywilizacji zachodniej, która wcześniej była tak chwalona za swoje braterstwo - spadek rewolucji francuskiej - rozczarowanie mogą wyjaśnić m.in. trudne początki - klasyczne w przypadku imigrantów - na francuskiej ziemi. Ponadto to przede wszystkim odkrycie w spojrzeniu innych własnej „odmienności” uderza nowoprzybyłych, którzy tak bardzo wierzyli w rewolucyjną równość. Twórczość literacka autorów żydowskich pochodzenia maghrebskiego we Francji jawi się więc jako nieodłączna od procesu historycznego, z którego zdaje sprawę przez słodko-gorzki stosunek do adopcyjnej matki-ojczyzny. Literatura ta rozwija się właśnie w relacji do tej zarazem ukochanej i rozczarowującej Francji, w chwili wspólnego doświad czenia, spełniając rozliczne funkcje społeczne: wspomnieniową, ,historiograficzną" i adaptacyjną.

\section{Podtrzymywanie pamięci zbiorowej}

Jak wiadomo, wspomnienie odgrywa podstawową rolę w tradycji żydowskiej ${ }^{44}$. Co więcej, okres, w którym francuscy pisarze żydowscy pochodzenia

42 G. Ben Aych Le Chant des êtres, s. 111.

K. Rubinstein Mémoire illettrée d'une fillette d'Afrique du Nord à l'époque coloniale, Stock, Paris 1979 , S. 289.

44 Y.H. Yerushalmi Zachor. Żydowska historia i żydowska pamięć, przeł. M. Wójcik, Żydowski Instytut Historyczny, Warszawa 2014. 
maghrebskiego publikują szczególnie dużo - lata 8o. XX wieku - jest naznaczony wzmożonym zainteresowaniem pamięcią. Do tego należy oczywiście dodać, niezależnie od tego kontekstu, zaprzątnięcie pamięcią, które wydaje się również wynikać z migracji.

W ramach literatury migracyjnej zachodzą dwa odrębne procesy związane z pamięcią: proces wspominania, który rozgrywa się na poziomie jednostkowym, oraz proces upamiętniania ${ }^{45}$, który dotyczy wspólnoty.

Wspominanie, przywołujące przeszłość, służy jako medium pamięci, lecząc ewentualne „rany” związane z utratą ziemi ojczystej lub ze znalezieniem się w nowym otoczeniu. Staje się dzięki temu substytutem zakorzenienia. Proces zakorzeniania przez samo pisanie ma więc na celu wpisanie jednostkowych i rodzinnych losów w ramy czasu; w ten sposób fakty są reorganizowane i zyskują pewien sens.

Ale choć pisanie sytuuje się w rejestrze jednostkowym, pozostaje również zakorzenione w przestrzeni społecznej i uczestniczy w umacnianiu więzi społecznych. Znana jest rola literatury w tworzeniu „wspólnot wyobrażonych” (imagined community) ${ }^{46}$ - żeby posłużyć się terminem Benedicta Andersona - we wzmaganiu poczucia przynależności członków danej grupy. Literatura migracyjna pozwala równieź, we właściwej sobie skali i właściwymi sobie środkami, umacniać i utrwalać uspołecznienie członków grupy migrantów, umożliwiając zbiorowe przyswojenie sobie wspólnego dziedzictwa ${ }^{47}$.

\section{Opowiadanie historii maghrebskich wspólnot żydowskich}

Zapis pamięci pociąga jednak za sobą unieruchomienie jej, „upomnikowienie", przez co pisarstwo migracyjne zyskuje funkcję historiograficzną. Opowiadanie wymaga opatrzenia fikcji lub autofikcji, powstających w wyniku tego procesu, tłem historycznym, gdyż, jak podkreśla Pierre Nora, potrzeba pamięci jest również potrzebą historij ${ }^{48}$. Należy tu jednak wziąć pod uwagę także szczególne położenie, w jakim znajduje się grupa migrantów przebywająca w nowym otoczeniu, oraz kontekst związany z bogatą tradycją

45 Mémoire et mémorialisation, t. 1, réd. D. Peschanski, Hermann, Paris 2013.

46 B. Anderson Wspólnoty wyobrażone: rozważania oźródłach i rozprzestrzenianiu się nacjonalizmu, przeł. S. Amsterdamski, Znak, Kraków 1997.

47 A.-M. Thiesse Communautés imaginées et littératures " Romantisme" 2009, no 143, s. 61-68.

48 Les Lieux de mémoire, t. 1, s. XXV. 
historiografii aszkenazyjskiej i ze zdominowaniem żydowskiego pisarstwa historycznego przez nazistowskie ludobójstwo.

Istotnie, historiografia dotycząca Żydów północnoafrykańskich rodzi się w latach 60 . XIX wieku, czyli ponad wiek później niż pisarstwo historyczne odnoszące się do Żydów europejskich. Od samego początku spisywanie historii Żydów zamieszkujących Afrykę Północną stanowi odpowiedź na zapotrzebowanie polityczne, związane z projektem nadania Żydom algierskim obywatelstwa francuskiego ${ }^{49}$. Wpisywanie ich historii w historię powszechną jest częścią projektu Żydów zamieszkujących Francję metropolitalną, chcących objąć zdobyczami rewolucji francuskiej swoich współwyznawców, aby ich „zreformować”. Dopiero koniec epoki kolonialnej przyniesie narodziny historiografii bardziej naukowej. Wynika to z faktu, że namysł nad przeszłością Żydów maghrebskich - zbyt świeży i stanowiący rezultat kolonizacji - nie od razu zaowocował spójnym nurtem historycznym.

W tym kontekście to literatura nienaukowa wzięła „odpowiedzialność" za opowiadanie historii wspólnot żydowskich ${ }^{50}$. Nie tylko pojawiła się ona wcześniej niż historiografia, ale i może pochwalić się większą liczbą opublikowanych dzieł.

Ta naukowa „luka” w pisarstwie historycznym dotyczącym Żydów północnoafrykańskich pozwala sformułować hipotezę odnoszącą się do historiograficznej funkcji literatury. Fikcja literacka byłaby w jej myśl formą odpowiedzi we własnym języku na doświadczenie przeszłości, w ramach której pisarz bierze na siebie zapis historii. Bo, jako że jest formą bardziej „elastyczną”, narracją kreatywną, innowacyjną, niewymagającą naukowej weryfikacji i niekoniecznie dążącą do objaśnienia przeszłości, literatura może w pewnych warunkach pełnić funkcję zapisywania historii, utrwalania jej.

W tych ramach literatura odgrywałaby więc podwójną rolę historiograficzną: opowiadałaby pewne elementy przeszłości, wprowadzając je do dziedzictwa za pośrednictwem pola literackiego, oraz uprawomocniałaby je w chwili, gdy uczestnicy pola uniwersyteckiego czy naukowego, a także opinia publiczna marginalizują historię danej grupy mniejszościowej lub dopiero zaczynają się nią interesować. Dzięki zapisaniu przeszłości przez grupę mniejszościową wspólnota narodowa uzyskuje dostęp do historii tej grupy i przyswaja sobie nowe spojrzenie na własną historię, co z kolei umożliwia dokonanie zmian w narracji narodowej. Ta obustronna wymiana pokazuje

C. Zytnicki Les /uifs du Maghreb.... 
bardziej ogólny mechanizm włączania grupy mniejszościowej do narodowej przestrzeni społecznej.

\section{Przyswajanie nowej rzeczywistości społeczno-kulturowej}

W kontekście migracji, w ramach której więzy rodzinne i przyjacielskie podlegają przemianie i przeorganizowaniu, narracja stanowi niezbędne zapośredniczenie, dzięki któremu moźliwe jest odtworzenie wielości spojrzeń na przeszłość i przedstawienie upragnionych wizji świata. Przepracowuje ona przeszłość pod kątem teraźniejszości, a teraźniejszość pod kątem przeszłości. Można by to nazwać funkcją adaptacyjną, ponieważ pozwala ona indywidualnie odtworzyć sens teraźniejszego życia, dostarczając jednocześnie schematów dopasowania grupy migrantów do wspólnoty, która ją przyjmuje. Proces ten odbywa się po omacku, a kultura i tożsamość obydwu grup niekoniecznie zostają w jego następstwie wymazane.

Pisarze odgrywają w ten sposób rolę raczej mediatorów i „pośredników kulturowych" niż inicjatorów, gdyż ich działanie - pisanie - nie jest (a w każdym razie nie zawsze jest) świadomym żądaniem akceptacji odmienności, domaganiem się miejsca czy przyjmowaniem roli tłumacza pośredniczącego między dwiema wspólnotami. Ich szczególna pozycja obserwatorów uczestniczących pozwala rozwijać nowe perspektywy, bez rezygnowania z przynależności do wspólnoty większościowej. W ten sposób literatura, dla której pożywką są zawsze obie rzeczywistości, przedstawia je obydwu grupom. Możemy więc uznać, że pisarze-migranci obracają się w „hybrydalnych ramach pojęciowych, które wytwarzają nowe tryby poznania"51.

To przemieszczanie się między dwiema wspólnotami „kwestionuje wyobrażenia o przynależności, ukazując różnego rodzaju sprzeczności i zakłócenia”, jak wyjaśnia Sherry Simon, dla której literatura migracyjna jest „tekstem, w którym zderzenie sprzecznych elementów wytwarza coś nowego, nieprzewidywalnego"52. Twórczość literacka pisarzy-migrantów świadczy o bogactwie społecznym i kulturowym wspólnoty, z której pochodzą. A więc to dzięki szczególnej wraźliwości i podwójnej perspektywie pisarze ci nie

51 W.D. Mignolo The Darker Side of the Renaissance, Literacy, Territoriality and Colonization, The University of Michigan, Ann Arbor 1995, S. 331.

52 S. Simon Hybridités culturelles, hybridités textuelles, w: Récit et connaissance, réd. F. Laplantine i in., Presse de l'Université de Lyon, Lyon 1998, s. 233. 
tylko rozwijają nowe formy narracji i wprowadzają innowacje językowe ${ }^{53}$, ale także ukazują inne schematy rozumienia świata. Bo to na drodze przyswajania sobie przez pisarzy nowego uniwersum społeczno-kulturowego oraz wpisywania w nie własnych wizji odbywa się na poziomie jednostkowym proces dostosowania do nowej rzeczywistości. Przez ten proces równieź cała wspólnota - zarówno narodowa, jak i ta skupiająca migrantów - uzyskuje dostęp do wyobrażeń właściwych miejscu ich pochodzenia oraz korzysta na przekształcaniu własnych przedstawień narodowych. Zwłaszcza literatura postkolonialna tworzy przestrzenie zapośredniczenia, w których moźna dostrzec nowe sposoby myślenia, mniej lub bardziej krytyczne zarówno wobec dziedzictwa kolonializmu, jak i ludów skolonizowanych.

Literatura tworzona we Francji w epoce postkolonialnej przez Żydów pochodzących z Afryki Północnej pozwala więc w szczególny sposób naświetlić zjawiska zachodzące wewnątrz pola literackiego. W istocie uczestniczy ona w dwóch procesach: współtworząc pamięć, walczy z zapomnieniem, ale też pozwala wejść w obręb przyjmującego migrantów społeczeństwa Francji metropolitalnej. Staje się strażniczką zbiorowej pamięci, a także umożliwia krytyczne spojrzenie na francuską rzeczywistość społeczną, wyrażając niepokój wywołany zetknięciem się z nią, a właściwie rozdźwiękiem między nią a wyobrażeniami na jej temat. Jednak to pisarstwo odwołujące się do szczególnych form wyrazu stanowi również apologię różnorodności kulturowej, dla której pisarze żydowscy pochodzenia maghrebskiego są pośrednikami. Ich twórczość, będąc jednocześnie nośnikiem specyficznej, lokalnej historii, współtworzy wieloraką przestrzeń narodową. Towarzyszy temu upiększanie rzeczywistości skolonizowanych krajów Maghrebu pod rządami Francji, jednak autorzy zachowują dystans względem cywilizacyjnej roli tej ostatniej, wychodząc od swoich własnych trudności ze znalezieniem sobie miejsca w społeczeństwie francuskim. 


\section{Abstract}

\section{Ewa Tartakowsky}

PARIS X NANTERRE

Between Memory and History: Jewish Writers from North Africa in France (a Sociological Approach)

Literary production by Jewish writers from North Africa in France reaches back to the 1950 s and has been gaining momentum since the 1980 s. These works function as vectors of memory, 'historiography' and adaptation. In a new environment, exile leads to recollection and memorialization processes, enabling the subject to fight against trauma and providing the migrant group with a framework of reference. Literature, which does not require a scientific framework, is able immediately to take over the narration of the past. These processes mediate between the exiled group and the host community, in which the exile literary work transcends the social realities that help construct the individual.

\section{Keywords}

migration literature, Jews in France, North Africa, sociology of literature 